\title{
SOCIAL WORK EDUCATION THROUGH OPEN AND DISTANCE LEARNING: AN INDIAN PERSPECTIVE
}

\author{
Dr. Bishnu Mohan DASH \\ Department of Social Work \\ Bhim Rao Ambedkar College \\ Delphi, India \\ Dr. Rambabu BOTCHA \\ Department of Social Work \\ Rajiv Gandhi National Institute of Youth Development \\ Chennai, India
}

\begin{abstract}
The paper traces the historical perspectives of open and distance education in India. It also discusses the various modalities and standards followed by various universities in offering social work education through open and distance learning (ODL) mode. It also highlights the achievements and challenges of social work education through ODL mode in India. The article will be extremely helpful to the academicians and policy makers in understanding the various dimensions of social work education through ODL mode in Indian context. The study recommends that Indira Gandhi National Open University model is one of the successful models of offering social work education through ODL mode.
\end{abstract}

Keywords: Social work education, distance learning, field work, IGNOU.

\section{INTRODUCTION}

Since its inception, social work education through ODL mode maintains a tension with regard to its recognition, often debated in India for being offered in ODL mode and is plagued by rigidities of the conventional institutions. But unfortunately, the social work in India is not recognized as a full-fledged profession as compared to other professions like medicine, engineering, law and others despite more than eight decades of its existence. Due to the absence of a systematic study to evaluate the effectiveness of social work education through ODL mode, it is always considered inferior to the programs offered through regular/ conventional mode. However, the easy access, affordability and convenience for the marginalized and disadvantaged sections of population the distance education system have received immense popularity and growth. In this paper, the authors have described the genesis of ODL mode of learning in India with particular reference to social work education. The paper describes the current status of social work in respect of various modalities and standards followed by various universities in India. Various aspects such as state wise distribution, credit system, duration, fee structure, use of multimedia approach, programs on offer were discussed. Besides secondary literature, University Grant Commission Report (UGC), the study has relied on primary data collected through the use of questionnaires administered to the heads of departments of social work of various universities. The minimum and maximum tenure, number of credits, guidelines for fieldwork, revision of materials, use of multimedia 
materials of various universities has been covered in the paper. Besides that, the achievements and challenges of social work education through ODL mode have been highlighted.

\section{CONCEPT OF OPEN AND DISTANCE LEARNING}

Open', 'distance' or 'flexible' learning, all terms used to describe alternatives to traditional taught courses-where the teacher and student interact directly through face to face contact (Horwath and Shardlow, 2000). It can be described as an organized educational activity which is based on the use of teaching materials in which constraints of study are minimized either in terms of access, time and pace, methods of study or any combination of these. In Open and Distance Learning mode, the learner can select his/her own place of study and gets relaxation in selecting his/her courses. The term 'open' in the open and distance learning system incorporates all the measures that encourage wide spread access to, and participation in education. In ODL, there is no full time face to face class room education. The teachers and learners interact at a distance. Occasionally, the learner meets the teachers in face to face counseling sessions. There is an educational organization which takes care of designing, preparation and delivery of learning materials to the learners. These are also called 'selfinstructional material' or' self - learning material' (Goel and Goel, 2009 cited in Aara, 2013). This system of learning has tried to remove barriers to learning such as entrance requirements, time constraints, program and course structure, lack of finance, geographical distance, and social and cultural factors, such as age, gender, ethnicity, and class, that have closed off and prevented attendance at the 'traditional 'system of learning. Open learning improves access to education, as it intends to be in line with the learning centered philosophies, creating flexible learning opportunities for a broad range of people from a wide range of backgrounds to enable them and empower them to have choice about how, when and where one learns (Bourn and Bottle, 2005; Collins, 2007; and Horwath and Shardlow,2000)

Zigerell (1984) states distance education is a form of instruction characterized "by the physical separation of teacher from student, except for the occasional face-to-face meeting allowed for by some projects." He points out that distance education differs from correspondence courses in that it "presupposes opportunities for student interaction, whether live or mediated, as well as for student independence." He also provides a distinction between distance education and distance learning, the former being the process and the latter focusing on the receiving end of distance education. According to the American Association of University Professors (1998), distance education is "the process whereby the education of a student occurs in circumstances where the educator and student are geographically separated, and the communication across the distance is accomplished by one or more forms of technology" (p. 34). Derrick (2003) defined distance education as simply any form of instructional delivery in which the student and teacher are not physically in the same location.

\section{DISTANCE EDUCATION IN THE GLOBAL CONTEXT: AN OVERVIEW}

The history of distance education is more than a century old. The institutionalized distance education, largely based on correspondence was established in Russia as early as 1850(Schlosser, 2002). Later a number of correspondence teaching polytechnic institutes came into existence in the Soviet Union in the 1920 s and early 1930s. There are other examples of purpose-built providers of post-secondary distance education courses which include the Toussaint and Langenscheidt Institute in Berlin (established in 1856) and the Swedish Libert Hermonds Institute established in 1898 with over 150,000 students each year at times (Schlosser, 2002). Probably the University of London was the first university to enroll students in a distance mode since 1858. In United States of America, Illinois State University in 1874; University of Chicago in 1891; University of Queensland in 1911 created new trends in distance education system by offering correspondence education to external students. 
In the United States, Canada and Australia, social work education through distance mode is offered since the early 1970s. The James Madison University, Virginia and the University of South Dakota, USA began social work education through distance learning in 1977 in consultation with the national council of social work education- the accrediting body. Similarly, the University of Moncton and the Maritime school of social work in Canada began to work jointly on a project aimed at de-centralizing social work education. In UK, distance learning in Social Work was first introduced in the Caledonian certificates in social service scheme in 1980-81 which was supported by six colleges and Universities (Srivastava, 2002 cited in Saumya, 2013). The guiding force for starting social work education through ODL mode is rooted in core principles of the profession: social justice, equality, and service to oppressed population (Abels, 2005; Metropolitan State College of Denver [MSCD]), Social Work Department, 2002 cited in Barclay, 2012). The economic and/or geographical barriers, and lack of opportunities for underserved communities created the need for alternative way for delivery of social work education (Abels, 2005; Raymond, 2005) Allen \& Seaman (2008) also mentioned that higher fuel costs and flexibility to accommodate work and family schedules also motivated for enrolling in online courses.

\section{HISTORICAL PERSPECTIVES OF OPEN AND DISTANCE LEARNING IN INDIA}

Due to the expanding base of elementary and secondary education after India's independence, the demand for higher education got increased. About five decades ego the policy makers felt the need of distance education in order to expand the base of higher education. Further the University Grants Commission in its report (1956-1960) suggested for starting up evening colleges, correspondence courses and award of external degrees. The Planning Commission, Government of India in its Third Five Year Plan emphasized the need for the introduction of correspondence education in the country. In the light of the observations made by the Planning Commission the Central Advisory Board on Education recommended the setting up of an Expert Committee under the chairmanship of Dr. D.S. Kothari, the then Chairman of UGC, to look into the proposal of introducing correspondence courses. The Expert Committee recommended the institution of correspondence courses in view of the greater flexibility, economic viability and innovative methods of imparting education. The committee also suggested that correspondence courses in India should be administered by the universities only and in the first instance, by one University, viz., the University of Delhi as a pilot project. So, in the year 1962 the University of Delhi established school of Correspondence courses and continuing education (now known as school of open learning, University of Delhi). The introduction of distance education in India further got impetus when the Education Commission (1964-66) highlighted the importance of correspondence education as a solution to the increasing pressure demands of higher education. During 1970-80 witnessed the growth and spread of correspondence course institutes named as directorates of distance education/centers of distance education to offer education through ODL mode. The Ministry of Human Resource Development, Government of India in its National Policy on Education (1986) highlighted the importance of Open University (OU) to further democratize opportunities for higher education and make it accessible to those residing in the remote regions of the country. Thus a new chapter in the field of distance education was created with the establishment of Dr. BR Ambedkar Open University, Hyderabad in 1982, followed by the establishment of Indira Gandhi National Open University (IGNOU) at the national level by an act of Parliament of India in 1985. Subsequently in 1987, Nalanda Open University (NOU) Patna, Bihar and Vardhman Mahaveer Open University (VMOU), Kota, Rajasthan was opened followed by Yashwantrao Chavan Maharashtra Open University (YCMOU), Nashik, Maharashtra was established in 1989.

Indira Gandhi National Open University besides offering programs of education and training through distance mode also acted for the promotion, coordination of the open and distance 
education system in the country and determining standards in such systems as it was bestowed powers by the Indian parliament. Accordingly, the Distance Education Council (DEC) was set up by IGNOU in 1991 as a statutory body under IGNOU Act which became operational in 1992. Due to the initiatives of the DEC and its interactions with various state governments, several open universities came into existence. Besides that, the Distance Education Council (DEC) took several initiatives for promotion, coordination and maintenance of standards of open and distance education system in the country. DEC has developed guidelines for regulating the establishment and operation of ODL institutions in the country.

The Madhava Menon committee (2010) constituted by the Ministry of Human Resource Development, Government of India recommended the new regulatory body i.e. Distance Education Council of India (DECI) for regulation of standards of education imparted through ODL mode. As an interim measure the regulatory authority of IGNOU is shifted to UGC vide MHRD order dated 29th December, 2012.

As on date (UGC Report, 2017) there are 17 single mode open universities (The data on single mode open universities is available with the University Grants Commission till the year 2010) in India having a network of about 11,000 study centers and about 70,000 academic counselors to support the learning needs of the students. The open Universities in India offer various kinds of programs viz. general courses, vocational courses, professional as well as technical courses.

Distance mode programs in dual mode Universities started with the Delhi University which started offering programs as correspondence courses in the year 1962. As on date there are about $\mathbf{2 5 0}$ distance education institutions in the dual mode universities and institutions which are offering programs through distance mode There are about 22 lakhs students who have enrolled in the DEIs of dual mode universities. The table given below reflects the year wise growth of ODL Institutions in the country.

Table 1. Year wise growth of ODL Institutions in the Country

\begin{tabular}{cccc}
\hline Year & $\begin{array}{c}\text { Dual Mode } \\
\text { Universities/ } \\
\text { Institutes }\end{array}$ & Single Mode OUs & $\begin{array}{c}\text { Total Distance } \\
\text { Education } \\
\text { Institutions }\end{array}$ \\
\hline 1962 & 1 & - & 1 \\
1975 & 22 & - & 22 \\
1982 & 34 & 1 & 35 \\
1085 & 38 & 2 & 40 \\
1990 & 46 & 5 & 51 \\
2000 & 70 & 9 & 79 \\
2005 & 106 & 13 & 119 \\
2010 & 242 & 14 & 256 \\
\hline
\end{tabular}

The enrolment of students in the ODL mode has increased over the period since the establishment distance education program started by Delhi University in 1962. With the total enrolment of 1,112 students in 1962, it increased to 29,500 students in 1970-71. Further it.

Increased significantly during the next two decades to about 6 lakh in 1990-91. In 2000-01, there were about 14 lakhs students studying through distance mode which further went up to about 18 lakhs students in 2005-06. The student enrolment further rose to about 37 lakhs in the year 2009-10. Thus, with fresh enrolment in ODL programs at approximately 40 lakh annually, the share of distance education in the GER is about $22-23 \%$, which is significant (UGC 2017). 
In the case of India, the social work institutions are concentrated mostly in urban areas and the need to reach the rural and the tribal areas can be fulfilled through distance learning. Besides, there has been a growing criticism of the elitist and urban slant in social work education (University Grants Commission Second Review Committee on Social Work Education, 1975). The existing systems of higher education have not been very accessible to persons in disadvantaged positions whether socially, geographically or economically. In terms of access and affordability social work through ODL (Open and Distance Learning) has the potential to impart training to the disadvantaged sections of the society. Besides, it offers the learners the flexibility of learning at ones pace, and working and studying at the same time. Social Work programs were offered in the conventional mode of education till the year 2004, when it began to be offered in the open and distance learning mode by IGNOU and later by some of the state open Universities. The BSW and MSW program at IGNOU (Indira Gandhi National Open University, New Delhi) was developed in response to requests from social service agencies across the country. The MSW program in IGNOU was started in 2008 also offered in Nepal and Ethiopia both in Hindi and English medium. The BSW Program was launched in the year 2004 also being offered both in the Hindi and English medium. (Saumya, 2013). Besides IGNOU, other Universities also started offering social work education through ODL mode (see table 3). Ramana (2012) reports because of high fee structures of the selffinanced institutions, distance education in social work is getting promoted as many consider it as the most economical and best option of receiving a post graduate degree in social work. In 2004, IGNOU launched the Bachelor in Social Work (BSW) program through ODL. (Thomas, 2013). This is the first social work program launched through ODL in India. The school of social work in IGNOU is the first school in India.

Gradually, the number of universities offering social work education through ODL has increased.

Till date only 25 Universities in India offer social work education through open and distance learning. These universities are located in 14 states and most of them are confined to their jurisdiction of their states only. Out of these, only 2 universities offer education at the M. Phil and PhD level. Except one institution, all the institutes' offers master's degree in Social work and only 7 universities/Institutions offer Bachelor degree in Social Work. Out of these 25 universities, only IGNOU is being the central university and others are mostly state universities and private institutions. In India more than 256 institutes/universities offer various courses through ODL mode, but only 25 institutes offer social work courses. Modalities and Standards of Social Work education through ODL Mode

\section{Duration and Credits of the MSW Program}

In general, there is an element of flexibility in ODL than conventional education in the duration, weightage for fieldwork, exam schedule, fee, etc. Since the learners for ODL programs would be from a variety of categories such as women, working people, backward classes, persons with multiple tasks, etc. they have to been given such flexibility. Learners should feel that they could complete the program within the maximum time period prescribed. 
Table 2. Duration and Credits of the MSW Program in some selected Universities

\begin{tabular}{lllll}
\hline SI. No & Name of the University & $\begin{array}{l}\text { Duration of the Program } \\
\text { Minimum }\end{array}$ & Maximum & Credits \\
\hline 1 & IGNOU & 2 Years & 5 Years & 66 \\
2 & UOU & 2 Years & 6 Years & 62 \\
3 & ANU & 2 Years & 5 Years & - \\
4 & Alagappa & 2 Years & 5 Years & - \\
5 & TNOU & 2 Years & 8 Years & 64 \\
6 & MPBOU & 2 Years & 5 Years & - \\
7 & UPRTOU & 2 Years & 4 Years & - \\
8 & CU & 2 Years & - & - \\
9 & TMV & 2 Years & - & - \\
\hline
\end{tabular}

Information was obtained from Indira Gandhi National Open University (IGNOU), Uttarakhand Open University (UOU), Acharya Nagarjuna University (ANU), Alagappa University, Tamil Nadu Open University (TNOU), Madhya Pradesh Bhoj Open University, UP Rajarshi Tandon Open University (UPRTOU), Chattisgarh University (CU), and Tilak Maharashtra Vidyapeet (TMV).

The research uncovers (Table 2) that in majority of the responding universities 2 years are required to complete Masters of Social Work (MSW) education. Four institutes reported that a maximum duration of 5-year are allocated to a student to complete MSW. While one institute reported that it allows 6 years to complete MSW, the maximum duration is 4-year and 8-year respectively for two separate institutions. Hence, this research has shown that there is no uniform pattern in deciding the maximum duration for completing MSW program. It would be ideal if the maximum duration was kept at 5 years. However, based on the nature of the learners who are enrolled for these programs, it can be varying from university to university and state to state, decided by the respective university authorities.

\section{Programs on Offer}

Several Open Universities in India are offering programs ranging from certificate to Ph.D program through ODL mode. Social work programs are also designed in India to be offered at various levels such as certificate, diploma, bachelor, master, pre-doctoral and doctoral. Among the $\mathbf{2 5}$ open universities in India, most of them have focused on offering social work programs at Master's level only.

In order to understand the status of social work programs on offer, the researcher had obtained relevant information. The findings reveal that all the nine $(\mathbf{1 0 0 . 0 0 \% )}$ universities are offering social work program at post-graduation level. However, the only university offering social work programs ranging from certificate to doctoral degrees is IGNOU.

\section{Material to Facilitate the Learners}

Based on the nature of the mode of delivery, there is a need to provide adequate guidance materials to the learners. In ODL, apart from self-learning materials, the institutions need to provide sufficient inputs through program guide, fieldwork manual, fieldwork journal, etc. The fieldwork manual should guide and direct the learners what to do, how to do and when to do. A detailed fieldwork manual is essential to increase the effectiveness of fieldwork. 


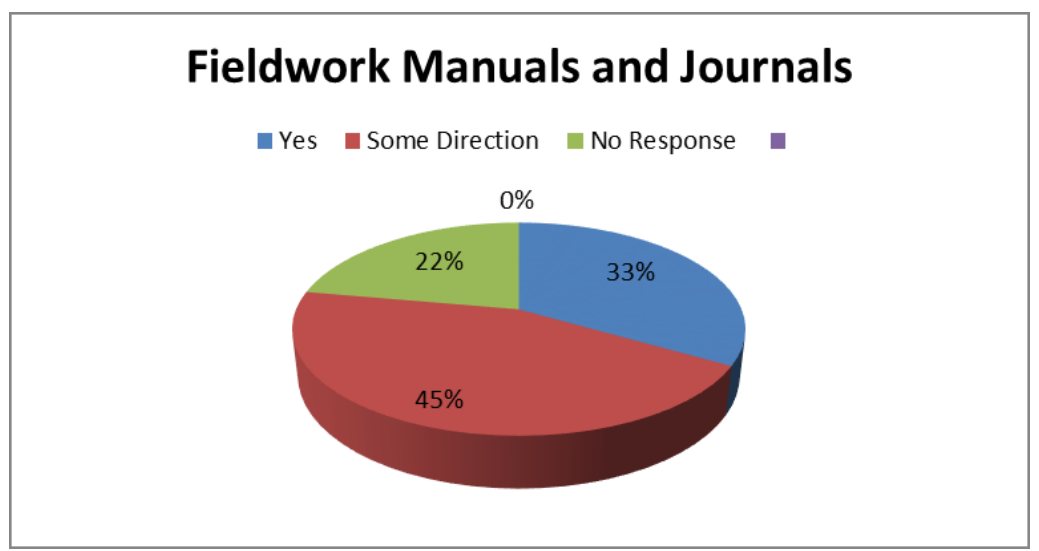

Figure 1. Material to facilitate the Learners

With regard to the provision of fieldwork manuals and fieldwork journals by the universities offering social work programs, the researcher collected information from all the six universities and the results are presented in the Figure (1). The data shows that more than half $(\mathbf{7 8 . 0 0 \% )}$ of the institutions have not provided any fieldwork manual or journal. Among the responding universities, two of them, which represent 22 per cent reported that they are facilitating their students with fieldwork manuals and journals, which will help them carry out their fieldwork in a systematic manner. Others may be providing some kind of direction to them to complete the fieldwork.

Some of the universities have clear written guidelines in their social work syllabus itself stating that one student has to make 10 observational visits. For this, the students have to choose an NGO and conduct 45 days fieldwork. After completion of the fieldwork, the student will be eligible to submit the report to the university. There will not be any fieldwork supervisor for the student. Without giving proper guidance either through a document or fieldwork supervision, some universities are completing their fieldwork component successfully.

\section{Fee Structure for MSW Program}

As far as the fee structure is concerned, it should be nominal for any program of study since the learners who approach ODL system are often from poor economic conditions with no facilities for higher education, or drop outs for the lack of financial support. Comparatively, the fee in ODL should be lesser than the fee in conventional education. Since social work is a professional program and there is a fieldwork component, the fee will be a little higher than Master's programs in other disciplines.

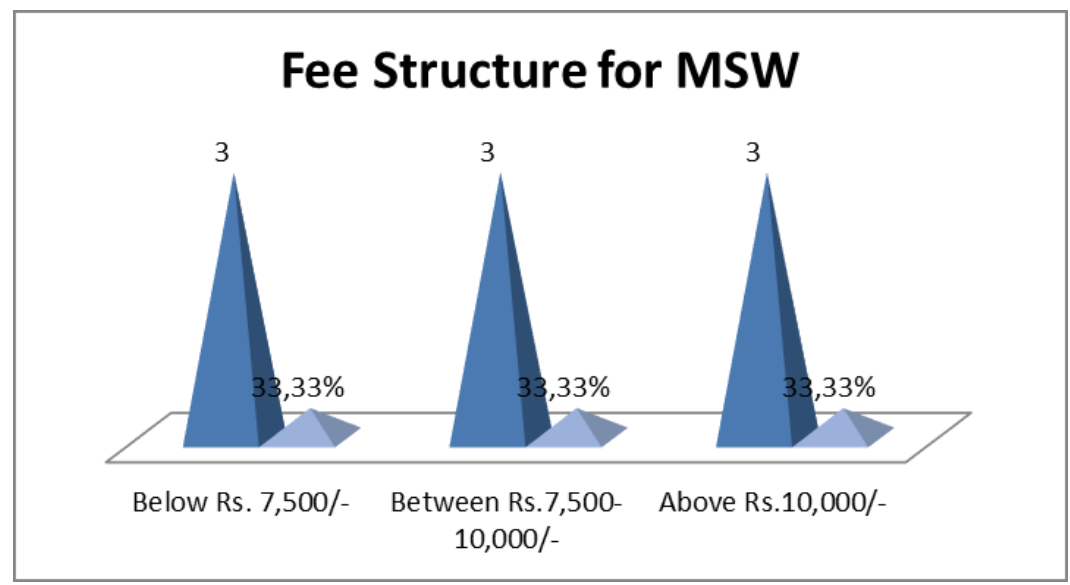

Figure 2. Fee Structure for MSW 
In order to understand the fee structure of the MSW program in various universities, the researcher obtained the information presented in the fig (2), which reveals that equal number of universities is following different fee structure. Among the nine responding universities considered for research, 3 of them which represents 33.33 per cent, charge less than Rs.7,500/- per annum; while three other universities charge between Rs.7,500/- to 10,000/-, and the rest three charge more than Rs.10,000/- per annum. Hence, it can be deduced that there is no uniform fee structure in the universities offering social work programs. The same has been found for Bachelor's degree programs too. Therefore, there has to be some sort of introspection among these universities to discuss and follow uniform fee structure.

\section{State Wise Distribution of Universities Offering Social Work through ODL}

According to the data available from the University Grants Commission (UGC) there are 25 universities offering social work through ODL in India. In fact, some of them are not really offering through ODL mode but mostly through correspondence education, which is completely different from ODL mode of delivery. The state wise distribution of universities presented in Table 5.1 shows social work education programs offered via the ODL mode in 21 universities scattered over 14 states.

Table 3. State Wise Distribution of Universities/Institutions offering Social Work education through ODL Mode

\begin{tabular}{llcclc}
\hline $\begin{array}{l}\text { Sl. } \\
\text { No }\end{array}$ & $\begin{array}{c}\text { Name of the } \\
\text { State }\end{array}$ & $\begin{array}{c}\text { No of } \\
\text { Universities/Institutions }\end{array}$ & $\begin{array}{c}\text { SI. } \\
\text { No }\end{array}$ & $\begin{array}{c}\text { Name of the } \\
\text { State }\end{array}$ & $\begin{array}{c}\text { No of } \\
\text { Universities/Institutions }\end{array}$ \\
\hline 1 & Andhra Pradesh & 02 & 8 & Maharashtra & 02 \\
2 & Haryana & 01 & 9 & Nagaland & 01 \\
3 & Karnataka & 01 & 10 & Rajasthan & 02 \\
4 & Chhattisgarh & 01 & 11 & Tamil Nadu & 05 \\
5 & Delhi & 01 & 12 & Uttarakhand & 01 \\
6 & Odisha & 01 & 13 & Uttar Pradesh & 03 \\
7 & MadhyaPradesh & 02 & 14 & West Bengal & 02 \\
\hline
\end{tabular}

In India, the maximum number of Universities/Institutions is located in the state of Tamil Nadu followed by Uttar Pradesh. Maharashtra, Madhya Pradesh, Rajasthan, West Bengal and Maharashtra have two universities/institution each. The rest of the states have one university each. However, given the vast geographical and demographical landscape of India with hugely populated 29 states and 7 union territories, the number of universities delivering social work program via ODL is meagre. If all the state open universities take initiatives to offer quality social work education through ODL program then all the states could be well covered. It is to be mentioned here that IGNOU, the largest Open University in India, having reach to all the states and union territories in the country is offering social work education through distance mode in various study centers.

\section{Reaching the Unreached: The IGNOU Effort}

The School of Social Work at IGNOU started offering social work programs from 2004 and has reached the unreached in the country with its programs of study. It reaches to large number of learners through its regional centers (RCs) and study centers located throughout the states and union territories. 
Table 4. Social Work Education through IGNOU Regional Centers

\begin{tabular}{|c|c|c|c|c|c|}
\hline SI. No & State / U.T & $\begin{array}{c}\text { RC- } \\
\text { IGNOU }\end{array}$ & $\begin{array}{l}\text { SI. } \\
\text { No }\end{array}$ & State / U.T & $\begin{array}{c}\text { RC- } \\
\text { IGNOU }\end{array}$ \\
\hline 1 & $\begin{array}{l}\text { Andaman \& Nicobar } \\
\text { Islands }\end{array}$ & 1 & 17 & Maharashtra & 3 \\
\hline 2 & Andhra Pradesh & 3 & 18 & Manipur & 1 \\
\hline 3 & Arunachal Pradesh & 1 & 19 & Meghalaya & 1 \\
\hline 4 & Assam & 2 & 20 & Mizoram & 1 \\
\hline 5 & Bihar & 4 & 21 & Nagaland & 1 \\
\hline 6 & Chandigarh & 1 & 22 & New Delhi & 3 \\
\hline 7 & Chhattisgarh & 1 & 23 & Orissa & 2 \\
\hline 8 & Goa & 1 & 24 & Pondicherry & - \\
\hline 9 & Gujarat & 2 & 25 & Punjab & 1 \\
\hline 10 & Haryana & 1 & 26 & Rajasthan & 2 \\
\hline 11 & Himachal Pradesh & 1 & 27 & Sikkim & 1 \\
\hline 12 & Jammu and Kashmir & 2 & 28 & Tamil Nadu & 2 \\
\hline 13 & Jharkhand & 2 & 29 & Tripura & 1 \\
\hline 14 & Karnataka & 2 & 30 & $\begin{array}{l}\text { Uttar } \\
\text { Pradesh }\end{array}$ & 4 \\
\hline 15 & Kerala & 3 & 31 & Uttarakhand & 1 \\
\hline 16 & Madhya Pradesh & 2 & 32 & West Bengal & 3 \\
\hline
\end{tabular}

Source: Gracious Thomas, Social Work Education through Distance Learning in India: A Reality, in Bhatt and Pathare (Eds: 2015), Social Work Education and Practice Engagement, New Delhi, Shipra Publications, New Delhi.

School of Social Work, IGNOU, has reached all the states with its 56 regional centers in India with an equal distribution of having minimum one center in every state (Table 5). While Uttar Pradesh and Bihar have 4 regional centers each, Andhra Pradesh, Maharashtra, Delhi, and Kerala each have 3 regional centers and the other states and union territories either have one or two regional centers. Every regional center in turn have hundreds of study centers; these study centers are facilitated by the regional centers and other supports and services are provided by the headquarters, IGNOU.

\section{Using Multimedia in ODL}

The universities are keen to harness the potential of information and communication technology (ICT) for teaching-learning process. IGNOU uses multi-media approach to impart education to the learners. The knowledge acquired through self-learning materials is supplemented and reinforced by audio-video components and counseling sessions conducted at the study centers to remove the apprehensions (if any) faced during this learning process. The multimedia approach for instruction followed by IGNOU comprises:

1. Self-instructional Written Material: Printed study material (written in selfinstructional style) for both theory and practical components of the programs are supplied to the learners in batches of blocks for every course (on an average one block per credit). A block, which comes in the form of a booklet usually, comprises of 3 to 5 units;

2. Audio-Visual Material Aids: The learning package contains audio and video CDs, which have been produced by the University Clarification and enhancement of understanding of the course material given to the learners. A video program is normally of 25-30 minutes' duration. The video cassettes are screened at the study centers during specific sessions, which are duly notified for the benefit of the learners. The video programs are also telecast on national networks mainly through 
Doordarshan and GyanDarshan. All Gyan Vani stations are broadcasting curriculum based audio programs. In addition, some selected stations of All India Radio also broadcast the audio programs. Learners can confirm the dates for the programs from their study centers. The information is also provided through the university website;

3. Counselling Sessions: Normally counselling sessions are held as per schedule drawn by the study centers. These are held mostly outside the regular working hours of the host institutions where the study centers are located

4. Teleconferences: Live teleconferencing sessions are conducted via satellite through interactive GyanDarshan Channel as well as simulcast on 'Edusat' channel from the university studios at EMPC, the schedules of which are made available at the study centers

5. Practicals/Project Work: Some programs have practical/project component also. Practicals are held at designated institutions for which schedules are provided by the study centers. Attendances for practical lessons are compulsory. For project work, comprehensive project guide in the form of a booklet is provided to the student along with the study materials (IGNOU, 2014).

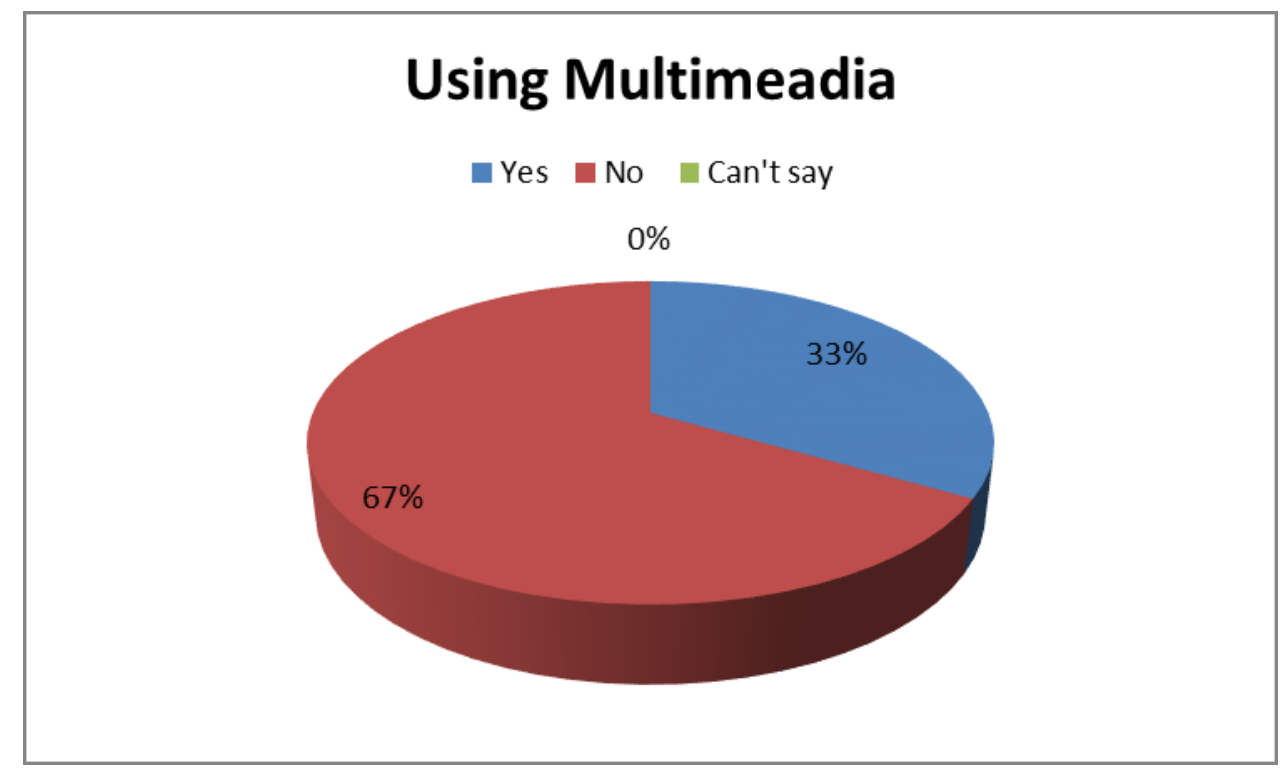

Figure 3. Using Multimedia in ODL

This research found that only $\mathbf{3 3}$ per cent of the universities use multimedia approaches in imparting social work education (fig.3). The remaining six universities, which represent 67 per cent fails to use any multimedia approaches in imparting social work education. However, multi-media approaches are very much effective in the process of teaching-learning, provided both the teachers and the students utilizes the available opportunities properly. Since many of the universities are not using this approach, it is advisable to start using it and it is essential while imparting education through open and distance mode. However, there is no mechanism to monitor students participation in the online learning services.

\section{IGNOU Model of Distance Education}

As mentioned above, IGNOU was established by an Act of the Parliament in September 1985, as an instrument for democratizing and augmenting opportunities for higher education, and widening access and providing a flexible and cost effective system of education. The university has carved a niche for itself in a short span and was conferred the honour of the "Center of 
Excellence in Distance Education" by the Commonwealth of Learning (COL). The COL has also conferred "Award of Excellence for Distance Education Material" to IGNOU.

Some of the features of the university are:

1. national jurisdiction

2. flexible admissions

3. Individualized study centers

4. use of modern education and communication technologies

5. student support services

6. modular programs, and

7. resource sharing.

The headquarters of IGNOU is at Maidan Garhi in New Delhi. In 2013, the university had 67 regional centers, about over $\mathbf{3 0 0 0}$ study centers, approximately $\mathbf{3 0}$ international study centers and has over three million students on the role making it the world's largest university.

Given the kind of nation-wide network supported by the multimedia components and expertise from the conventional system in the country, IGNOU has become an alternate model to launch quality program of study in social work for the wide variety of student population across the country from Kashmir to the Andaman and Nicobar Islands.

IGNOU has perhaps the unique status of employing maximum number of professional social workers at its headquarters as well as the regional centers. While the school of social work alone has eleven faculties having postgraduate degree in social work, the university has employed several academics in its other schools, regional centers as well as study centers. Almost 1500 academic counselors having MSW support the teaching and supervision of social work students both within and outside the country. IGNOU provides research scholarships to about one dozen scholars from social work to pursue M.Phil/PhD programs.

The university offers several programs (228 in 2013) leading to certificates, diplomas and degrees of professional, vocational, technical and awareness generating areas. IGNOU is also offering BSW, MSW, PGDSW, M.Phil and Ph.D in social work. In fact, IGNOU is the only university in India to have indigenously developed textbooks on social work, supplemented with audio and video programs in both English and Hindi. There is also interactive radio counselling and teleconferencing sessions for social work students, which no other university in the country provides.

\section{The School of Social Work at IGNOU}

The School of Social Work (SOSW) was established on 16 August 2007 with the approval of the President of India who is also the Visitor of the university. The school currently offers eight programs of study in social work and two on HIV and family education. Over 30, 000 students currently pursue these programs of study through ODL from within India and twelve other countries from India's neighborhood and the African continent. This makes SOSW the largest school of social work. SOSW gives utmost importance to research and has about 60 students pursuing M.Phil / PhD currently. The school also recognized Rajagiri College of Social Sciences, Kalamassery as a Research Center for research work.

SOSW is known for developing indigenous material on social work keeping in view the core value of competence. The school has produced over 200 titles with ISBN numbers and offers over 60 courses on social work and closely related topics in both English and Hindi. Apart from high quality print materials, the school also has produced about 75 video programs, which are on regular telecast and most of them are available in YouTube. The school also has direct 
interactive teleconferencing sessions and interactive radio counseling for social work students within India and for the students covered under Pan African - e- network.

Keeping in view the recommendations of the first and Second Review Committee Report of the UGC on social work education, the SOSW has developed its programs of study addressing the issues of the rural and tribal population of the country. The school also revises its programs at least once in five years. The school has field action projects in open community settings as well as in Tihar Jails. Since 2004, the school has been organizing one Annual National Seminar on Social Work every year. It also organizes state level seminars all across the country.

SOSW has a 100 million project through the Catholic Bishops Conference of India (CBCI) Chair. The school also houses the Mother Teresa Chair and the Center for Tibetan Studies. SOSW extensively participates in extension activities including reaching out to the homeless and victims of natural calamities all over the country. The school has the distinction of launching the first MSW program with specialization in Philanthropy and another one on Counseling. These programs originally started, as on- campus programs and have now became part of the ODL programs of the school.

\section{Social Work Practicum}

The social work practicum components in all the programs of study being offered by IGNOU comprise 40 to 50 percent of the total weightage. While NACC and UGC criteria for practicum range from 33 to 40 percent, IGNOU has gone beyond those minimum standards to ensure that the social work programs through ODL is well designed and strongly founded to be professional in nature. For each program, separate fieldwork journals have been prepared giving objectives and targets for each year. The practitioners' guide and program guide spell out every detail to help both the student as well as the field supervisor. A professionally qualified supervisor having post-graduation in social work is guiding every student.

Perhaps IGNOU is the only university offering Doctoral Programs in social work with compulsory components of field practicum. The school does not admit graduates from other disciplines to its doctoral program, which is otherwise a practice even in central universities located in Delhi. Hundred percent attendances is mandatory in field practicum for all social work programs of IGNOU.

\section{SOCIAL WORK EDUCATION THROUGH OPEN AND DISTANCE LEARNING: ACHIEVEMENTS AND CHALLENGES}

ODL occupies a significant place in the Indian higher education system as it has played a major role in enhancing the gross enrollment ratio and democratization of higher education to large chunks of the Indian population. It has been successful in reaching out the unreached and provided a viable option in providing opportunities particularly for the disadvantaged groups such as those living in remote and rural areas, working people and women etc. for lifelong learning which has become more of a necessity in the present day globalized knowledge society. It has gained wider acceptance in India as it offers college/university level of education which is flexible and open in terms of methods and pace of learning; selection of courses and subjects, eligibility for enrollment, age of entry, conduct of examination and implementation of the programs of study. Besides providing opportunities for adding qualifications, it has remained an important source for updating knowledge and acquiring new knowledge in diverse disciplines.

India has one of the largest DE systems in the world, second only to China (UGC, 2017). Distance education in India is offered by various types of educational institutions viz. National Open University, State Open Universities; Distance Education Institutions (DEIs) at 
Institutions of National Importance; Central Universities; - State Universities, deemed to be Universities and State Private Universities. Besides that, distance education is also offered in various in various DEIs at Stand-alone Institutions like - Professional Associations, Government Institutions; and Private institutions.

In terms of student learning and satisfaction, distance education courses have been found to be comparable to traditional classroom courses (Schoech \& Helton, 2001). Rafferty \& Waldman (2006) reiterated the need for social workers to stay abreast of communication technologies that support virtual contact and practice. Distance education has become a critical method of delivering social work education because it has opened access to education for many people, including those in rural areas and in underserved communities, those who are far along in the careers, and those who are financially strained. Recently social work education is being completely delivered through distance education via online. The University of North Dakota and Texas State University offer complete MSW program through online. The Metropolitan State College Denver and Florida State University offers on line BSW and MSW program respectively. Even in Canada, the University of Calgary offers a one year MSW degree online. In one study 'online student' outcomes were comparable to the outcomes for 'face-to face' students in terms of knowledge and skills gained in class (Wile \& Vinton, 2006).

One of the major limitations in the distance education in social work is the lack of effective field work practice and supervision leading to lack of competency in doing work in the field. With respect to assessing practice effectiveness, the profession faces a much more complex and daunting task than those in professions where outcomes are more concrete. Documenting those social workers interventions halted further delinquency or resolved marital conflicts is usually more difficult than measuring whether an engineer's plans produced a good bridge or a surgeon's operation cured a physical defect (Bisno \& Cox, 1997). The social work education through distance learning has minimal recognition in India. It is also a fact that social work profession in India is struggling for professional status despite eight decades of its existence (Dash, 2016).A number of studies have been conducted to evaluate the effectiveness of distance education. The various aspects of distance education like learner outcomes, cost effectiveness, growth of students have been studied by Garrison, 1987; Fulford \& Zhang, 1993; Holmberg, 1989; and Verduin \& Clark, 1991 reveals the effectiveness of distance education. Some other researchers conducted by Berman \& Wilson, 1995; Forster \& Rehner, 1998; Rooney \& Macy, 1998; Wise \& Petracchi,1998; Raymond, 1996; Thyer, Polk \& Gaudin, 1997 have examined the quality of distance education programs in social work in terms of technology related issues, faculty and students perceptions and cost effectiveness revealed positives outcomes of distance education.

It is gaining prominence because it reaches a broader student audience, addresses student needs, saves money, and uses principles of modern learning pedagogy (Zarghami and Hausafus, 2002). Although differences exist between distance education and face-to-face instruction, evidence suggests that distance education can make graduate study available to a larger number of students and that it is at least as effective as classroom instruction, in terms of student learning (Weinbach, Gandy \& Tartaglia, 1984 quoted by Blakely 1992). However, in India, social work education through open and distance mode is still looked at by social work educators and practitioners with suspicion, some have rejected it altogether while some still question, exhibit inhibition, raise doubts and concerns and are still not ready to accept it completely. Lange (1986, cited from Pawar, 2000 cited in Saumya, 2013). There is no research available in India on effectiveness of social work through distance education as it is still in its nascent stage. The flexibility of the system and the rapid advancement of technology has contributed to the recognition of ODL as an effective means of education. Though the technological facility to impart distance education varies from Institutions to institutions, it is accepted by learners who are marginalized and disadvantaged owing to various reasons. The demand for 
distance education in India is growing as it provides flexibility in learning. ODL offers a more convenient and cost effective method of learning to its students. Governments worldwide are promoting more and more the use of open and distance learning as a complementary approach to traditional educational structures in order to meet the new and changing demands for education and training in the twenty fifth century (Gutierrez, 2010).

\section{CONCLUSION}

The article will definitely be helpful to the readers, academicians in social work and policy makers in understanding the various dimensions, modalities of social work education through ODL mode in India due to the unavailability of any major research in social work education through ODL mode. The IGNOU model has been presented for understanding how education can be imparted through ODL effectively. After studying various aspects, it was observed that IGNOU model of social work education through ODL mode is one of the successful model which can be replicated by other universities/institutions.

\section{BIODATA and CONTACT ADDRESSES of AUTHORS}

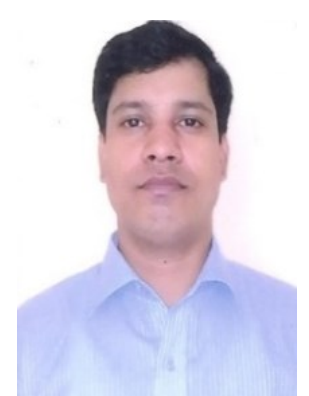

Dr. Bishnu Mohan DASH is Assistant Professor (Senior Scale) in Department of Social Work at Bhim Rao Ambedkar College (University of Delhi). Dr Dash has completed his M.Phil and PhD from University of Delhi and has completed ICSSR Post-Doctoral Fellowship (thesis submitted in 2017). He has also authored/coauthored/edited eight books. He has published more than thirty papers in various reputed National and International Journals and contributed chapters for Post Graduate Course in Social Work (MSW)/ Social work and Counseling of Indira Gandhi National Open University, New Delhi. He is also an editorial board member in several national and international journals. He has completed a number of research projects and organized various workshops and seminars and has been a very active academician and researcher in social work. His areas of interest are Rural Development, Child welfare, social work education.

Dr. Bishnu Mohan DASH

Department of Social Work,

Bhim Rao Ambedkar College(University of Delhi),

Main Wazirabad Road, Yamuna Vihar, Delhi, Postal code-110094, INDIA

Phone: 0-9910718789

Email: bishnudash2006@gmail.com

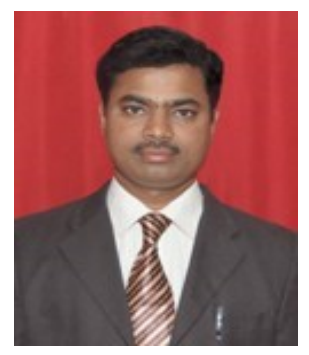

Dr. Rambabu BOTCHA is the Assistant Professor, Department of Social Work, Rajiv Gandhi National Institute of Youth Development, Tamilnadu (India). He has received his Ph.D and M. Phil in Social Work from the Indira Gandhi National Open University (IGNOU), New Delhi. He has published 20 papers in peer reviewed national/international journal/edited volumes to his credit. He has presented 22 papers in various national and international conferences. His area of Interest is social work education, field work practice and youth development.

Dr. Rambabu BOTCHA

Department of Social Work,

Rajiv Gandhi National Institute of Youth Development,

Sriperumbudur, Chennai, Postal code-602105, India

Phone: 8527537803

Email: ramamsw123@gmail.com 


\section{REFERENCES}

Aara, R. (2013). Supervision in social work practicum in ODL and Conventional system. a comparative study, thesis submitted to the school of social work, Indira Gandhi National Open University, New Delhi.

Abels, P. (2005). The way to distance education. In P. Abels (Ed.), Distance education in social work: Planning, teaching, and learning (pp. 3-22). New York, NY: Springer.

Allen, I. E., \& Seaman, J. (2008). Staying the course: Online education in the United States, 2008. Needham, MA: Sloan Consortium (Sloan-C). Retrieved from http://sloanconsortium.org/publications/survey/staying_course

American Association of University Professor (1998). Subcommittee on distance learning, 84(3), 30-38.

Barclay, B. (2012). Undergraduate social work students: Learning interviewing skills in a hybrid practice class. Thesis submitted in Colorado state university, Fort Collins, Colorado. P.2

Berman, G. S., \& Wilson, B. R. (1995, March). A case study: Social work education by distance delivery in a remote arctic region of northwest Alaska. Paper presented at the Annual Program Meeting of the Council on Social Work Education, San Diego, CA.

Bisno, H., \& Cox, F. (1997). Social Work Education: Catching up with the present and the future, Journal of social work education, 33(2), 373-387.

Blakely, T. J. (1992). A model for distance education delivery. Journal of Social Work Education, Vol. 28, No. 2, 214-221.

Bourn, D., \& Bootle, K. (2005). Evaluation of a Distance Learning, Post Graduate Advanced Award in Social Work Program for Child and Family Social Work Supervisors and Mentors. Social Work Education, 24 (3), 343 - 362. DOI: 10.1080/02615470500050644.

Collins, S. (2007). Open and Distance Learning in Qualifying Social Work Education in Britain and the USA: Celebrating Diversity and Difference. Social Work Education, 27(4), 422 - 439. DOI: 10.1080/02615470701379792.

Dash, B.M. (2016). Eight decades of social work education in India: Still Struggling for Professional Status" Millennium Post, July 16, p.8

Derrick, M.G. (2003). Creating environments conducive for lifelong learning. New Directions for adult and continuing education, 100 (5-18).

Forster, M. \& Rehner, T. (1998). Information technologies, teaching to use: using to teach. Binghamton, NY: Haworth Press.

Fulford, C.P. \& Zhang, S. (1993). Perceptions of Interaction: The critical predictor in distance education. American Journal of distance education, 7(3), 8-21

Garrison, D.R. (1987). Researching drop out in distance education. Distance education, 8(1), 95-101.

Goel, A., and Goel, S. L. (2009). Distance Education: Principles, Potentialities and Perspectives. New Delhi: Deep and Deep publication.

Gutierrez, I. P. (2010). Global Perspectives in Open and Distance Learning and Open Learning Resources. Distance Learning, 7(1), 16-21. 
Holmberg, B.(1986). The growth and structure of distance education. London: Croom-Helm.

Horwath, J., \&Shardlow, S. M. (2000). Empowering learners through open (distance) programs: an evaluation of a practice teaching program. Social Work Education, 19 (2), 111- 123. DOI: 10.1080/02615470050003502.

Metropolitan State College of Denver, Social Work Department (2002). Proposal for distance education. Presented to the Council on Social Work Education's Commission on Accreditation for review. Denver.

Patchner, M. A., Wise, S., \& Petracchi, H. (1998, March). Teaching research: An evaluation of ITV and face-to-face instruction. Paper presented at the Annual Program Meeting of the Council on Social Work Education.

Pawar, M. (2000). Social Work Education through Distance Mode in India: A Proposal. Indian Journal of Open Learning. 61 (2), 196-211.

Rafferty, J. \& Waldman, J. (2006). Fit for virtual social work practice. Journal of technology in human services, 24(2-3), 1-22.

Raymond, F. B. (1996). Delivering the MSW curriculum to non-traditional students through interactive television. In E. T. Reck (Ed.), Modes of professional education II: The electronic social work curriculum in the twenty-first century. (Vol. 20). Tulane studies in social welfare. New Orleans, LA: School of Social Work, Tulane University

Raymond, F. (2005). The history of distance education in social work and the evolution of distance education modalities. In P. Abels (Ed.), Distance education in social work: Planning, teaching, and learning (pp. 23-40). New York, NY: Springer

Saumya (2013). Social work through distance education: Commitments for justice, equity, and inclusion of the marginalized. Perspectives in social work, vol.28 (1 \&2 ), 47-64

Schoech, D. \& Helton, D. (2001). Qualitative and Quantitative analysis of a course taught via classroom and internet chat room. Qualitative social work, 1(1), 111-124.

Srivastava, M. (2002). A comparative study on current trends in distance education in Canada and India. Turkish Online Journal of Distance Education, 3(4), Available at: http: / / tojde.anadolu.edu.tr/tojde8/articles/srivastava.htm

Thomas, Gracious (2015) Social Work Education through Distance Learning in India: A Reality, in Bhatt, S. \& Pathare, S. (Eds: 2015), Social Work Education and Practice Engagement, New Delhi, Shipra Publication.

Thomas, G.(2013), Supportive role of the "CBCI Chair" at IGNOU in ODL program development. AAOU Journal, Vol.8, No.1, 83-89.

Thyer, B.A.; Polk, G.; Gaudin, \& J.G.(1997). Distance learning in social work education: A preliminary evaluation. Journal of social work education, 33, 363-367.

University Grants Commission, (1980). 'Review of Social Work Education in India: Retrospect and Prospect', Report of the Second Review Committee, New Delhi.

Vreduin, J.R \& Clark, T.A. (1999). Distance education: The foundations of effective practice:San Francisco: Jossey- Bass.

Weinback, R.W; Gandy, J. \& Tartaglia, L. (1984). Addressing the needs of the part time student through interactive television: An evaluation. Arete, 9, 12-29.

Wilke, D. \& Vinton, L. (2006). Evaluation of the first web based standing MSW program. Journal of social work education, 42, 607-620. 
Zarghami, F. \& Hausafus, C.O. (2002). Graduate student satisfaction with interactive televised courses based on the site of participation. The Quarterly Review of Distance Education, 3(3), pp. 295-306.

Zigerell, J.(1984). Distance Education: An Information Age Approach to Adult Education. Information Series no. 283,. Columbus: ER IC Clearinghouse on Adult, Career, and Vocational Education, The Ohio State University, 1984. (ERIC Document

Reproduction Service No. ED 246 311). 